\title{
Experimental inoculation model of Walker 256 carcinoma into vagina and cervix uteri of female rats ${ }^{1}$
}

\author{
Modelo experimental de Tumor de Walker 256 em vagina e colo de útero de ratas
}

\author{
Nara Macedo Botelho Brito², Marcus Vinicius Henriques Brito ${ }^{3}$, Rita de Kássia Vidigal Carvalho ${ }^{4}$, Lia Tavares de \\ Moura Brasil Matos', Thiago Sousa Veloso ${ }^{4}$, Diego Matos de Vasconcelos ${ }^{4}$, Rosângela Baía Brito ${ }^{5}$ \\ 1. Research performed at Laboratory of Experimental Surgery, State University of Pará (UEPA), Brazil. \\ 2. PhD, Associate Professor, Department of Specialized Health, UEPA, Pará, Brazil \\ 3. PhD, Associate Professor, Department of Integrated Health and Coordinator of Laboratory of Experimental Surgery, UEPA, Pará, Brazil. \\ 4. Graduate student, UEPA, Pará, Brazil. \\ 5. MD, Pathologist, UEPA, Pará, Brazil.
}

\begin{abstract}
Purpose: To establish an inoculation model of Walker 256 carcinoma on cervix uteri and vagina of rats.

Methods: Fifteen female rats were used, and assigned to three groups each one with five rats: group A - rats with $4 \times 10^{6}$ cells of Walker 256 carcinoma without acid acetic inoculation; group B - rats with 2x106 cells of Walker 256 carcinoma with acid acetic inoculation and group C: rats with 4x106 cells of Walker 256 carcinoma with acid acetic inoculation. The day before tumor cells inoculation the rats from groups B and C were anaesthetized with diethylether and 0,3 ml of acetic acid was inoculated into their vaginas. Tumor cell inoculation into the vagina and cervix was done under general anesthesia with diethylether. Then a endocervical brush was used to scrape the vaginal wall and after that 0,3 ml of the liquid containing tumor cells was inoculated on the vagina and cervix. For the tumor analysis, animals were euthanized at day 12 following tumor cell implantation by an excessive inhalation of diethylether. Tumor was resected entirely and weighed and the tumors were then sectioned and counter stained with hematoxylin and eosin for histopathologic evaluation. It was also calculated the percentage of tumor equivalent to the body weight by the formula: $\mathrm{P}=$ tumor weight / body weight x 100. Data were analyzed by one-way analysis of variance - ANOVA. P values $<0.05$ were taken to indicate statistical significance. Results: Implantation and growth on GB and GC was 100\% and on GA 20\%. There was no statistical difference between GB and GC averages. Conclusion: According to the methods used, the Walker 256 carcinoma inoculation model into vagina and cervix have an implantation and growth rate of $100 \%$ when associated with previous acid acetic inoculation and there is no behavioral difference between using $2 \times 10^{6}$ or $4 \times 10^{6}$ cells on its inoculation.
\end{abstract} Key words: Carcinoma 256, Walker. Cervix uteri. Vagina. Disease models, animal. Rats.

\section{RESUMO}

Objetivo: Estabelecer um modelo de inoculação de Tumor de Walker 256 em vagina e colo de útero de ratas. Métodos: Foram utilizadas 15 ratas fêmeas, virgens, adultas, pesando entre 200-250g, distribuídas em três grupos de estudo com cinco animais cada: grupo A (GA): ratas com tumor de Walker 256 em concentração de 4x10 $0^{6}$ sem ácido acético; grupo B (GB): ratas com tumor de Walker 256 em concentração de 2x10 células com ácido acético; grupo C (GC): ratas com

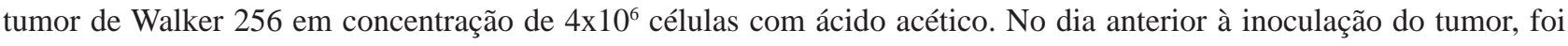
realizada a inoculação de 0,3 ml de ácido acético a 10\% na vagina das ratas de GB e GC; no dia seguinte, tanto estas como as ratas do grupo GA foram anestesiadas, feita a escarificação da parede vaginal com uma escova de endocérvice e

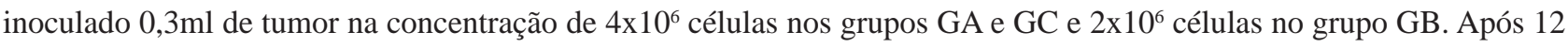
dias, foi realizada a eutanásia e removido o tumor em bloco com vagina e cornos uterinos para análise, sendo pesado e averiguado seu volume e calculado as relações entre o seu peso e o peso final da rata e o seu volume e o peso final da rata. Os dados foram colhidos e submetidos à análise estatística pelo método ANOVA (um critério). Resultados: A pega em GB e GC foi 100\% e em GA 20\%. Não houve diferença estatística entre as médias obtidas entre GB e GC. Conclusão: De acordo com a metodologia utilizada, o modelo de tumor de Walker 256 na vagina apresenta pega de 100\% quando associado a ácido acético e não há diferença de comportamento com a inoculação de 4x1060u 2x106 células.

Descritores: Carcinoma 256 de Walker. Colo do útero. Vagina. Modelos animais de doenças. Ratos. 


\section{Introduction}

Cervical cancer is the third most common type of cancer in Brazilian women ${ }^{1}$ and it is 30 to 60 times more common than vaginal cancer. Considering the facts that the vagina and the cervix are contiguous structures from the female reproductive tract, that both organs are composed by Malphigi epithelium, and both structures are subject to the same environmental stimulation, the difference between the cancer incidences can be attributed to the fact that glands are present on most external cervical areas. ${ }^{2,3}$ Primary vaginal neoplasm is rare. Martins (2002) showed that only $2.3 \%$ of female reproductive organs' cancers originate from the vagina ${ }^{2}$. In the other hand, it is known that the vagina is a frequent site of endometrial, ovarian, urethral, bladder and rectal cancer's metastases (insert reference). The most common type of metastases found is epidermoid, originated from the cervix or vulva. ${ }^{2}$ Aiming at reducing the deaths caused by cancer, cytotoxic and hormonal drugs, as well as biological agents, have been used on cancer treatment. However, such drugs often have pitfalls, due the fact they have high toxicity against noncancerous cells, and also because various types of cancer cells are resistant against therapy. Therefore, development and test of new anti-cancer substances is necessary. ${ }^{4}$ One of the best ways to test novel substances is to use it in experimental tumors. The induction model of Walker 256 carcinoma has been largely described in the literature. (insert references) It is a well described neoplasm, easily maintained in laboratory conditions, has fast and uniform growing, rarely regresses, and its efficiency has been already confirmed in therapeutical tests. ${ }^{5}$ There are numerous Walker 256 carcinoma implant site models, such as skin, ${ }^{6}$ muscle, ${ }^{5}$ subcutaneous tissue, ${ }^{5}$ gastric walls, ${ }^{7}$ lungs, ${ }^{8}$ kidneys, ${ }^{9}$ among others. However, to the best of our knowledge, there are no reports of gynecological Walker carcinomas. Since the incidence of gynecological cancers is high (insert reference), we believe that it is necessary to develop a vaginal tumor model in order to test novel drugs and phytotherapics against gynecological cancer in the future.

\section{Methods}

The Animal and Human Research Committee of the Pará State University approved all animal experiments. In addition, all animals used in this study received the humane care in compliance with the Brazilian law of animal vivisection, the rules of Brazilian College of Animal Experimentation. Fifteen female rats weighing $200-250 \mathrm{~g}$ were obtained from Evandro Chagas Institute (Belém PA). Animals were kept under standard rodent laboratory housing at conditions with 12 hours day/night cycles and given standard rodent chow diets and tap water ad libitum. The Walker 256 carcinoma cell line was obtained from Federal University of Ceará (Fortaleza - CE). The cell line was maintained with successive transplantations by intramuscular inoculation on the paw of Wistar rats. The tumor was removed from donors and put on a Petri dish containing $4 \mathrm{ml}$ of saline and $1 \mathrm{ml}$ of gentamicin. The tissue was then shredded into pieces into a solution which was then filtered and diluted to concentrations of $4 \times 10^{6}$ or $2 \times 10^{6}$ cells. Five animals were assigned to each group and treated as following:

Group A: rats inoculated with $4 \times 10^{6}$ cells of Walker 256 carcinoma without previous acid acetic inoculation

Group B: rats inoculated with $2 \times 10^{6}$ cells of Walker 256 carcinoma with previous acid acetic inoculation

Group C: rats inoculated with $4 \times 10^{6}$ cells of Walker 256 carcinoma with previous acid acetic inoculation

The day before tumor cells inoculation on the assigned groups, the rats were anaesthetized with diethylether and $0,3 \mathrm{ml}$ of acetic acid was inoculated into the rats' vaginas. Tumor cell inoculation into the vagina and cervix was done under general anesthesia with diethylether. Then a endocervical brush was used to scrape the vaginal wall (Figure 1) and after that $0,3 \mathrm{ml}$ of the liquid containing tumor cells was inoculated on the vagina and cervix. For the tumor analysis, animals were euthanized at day 12 following tumor cell implantation by an excessive inhalation of diethylether. A laparotomy was performed in order to analyze the presence of macroscopic metastasis sites and to allow the removal of uterus, vagina, cervix and rectum for further analysis and separation of cervix and vagina. Tumor was resected entirely and weighed, representative photographs were taken and the tumors were then sectioned and counter stained with hematoxylin and eosin for histopathologic evaluation. It was also calculated the percentage of tumor weight equivalent to the body weight by the formula: $\mathrm{P}=$ tumor weight / body weight $\mathrm{x} 100$.

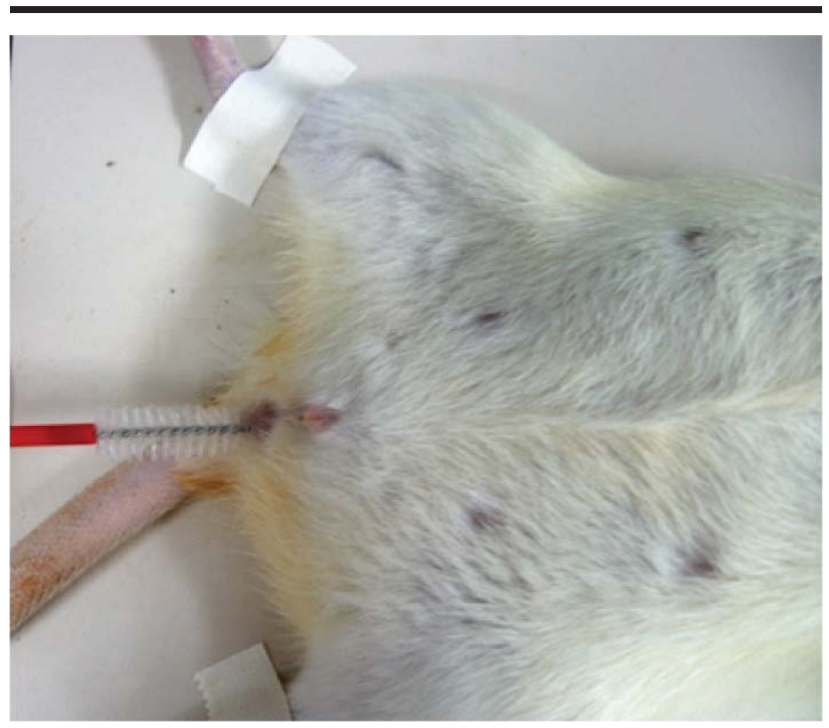

FIGURE 1 - Vaginal scraping 


\section{Results}

Walker 256 carcinoma inoculated on vagina and cervix had an implantation and growth rate of $100 \%$ on groups B and C and only $20 \%$ on group A. There were no distant metastasis sites and near structures were affected by contiguity (Table 1). The tumor affected the entire organ, obstructing the path (Figure 2). In addition there was expansive growth with urethra and rectum compression, causing urine and feces retention (Figure 3). Microscopically, the entire organs' walls were affected by the neoplasm, with loss of their normal characteristics. The cell line was undifferentiated (Figure 4). There were no statistical difference between groups B and C (Table 2).

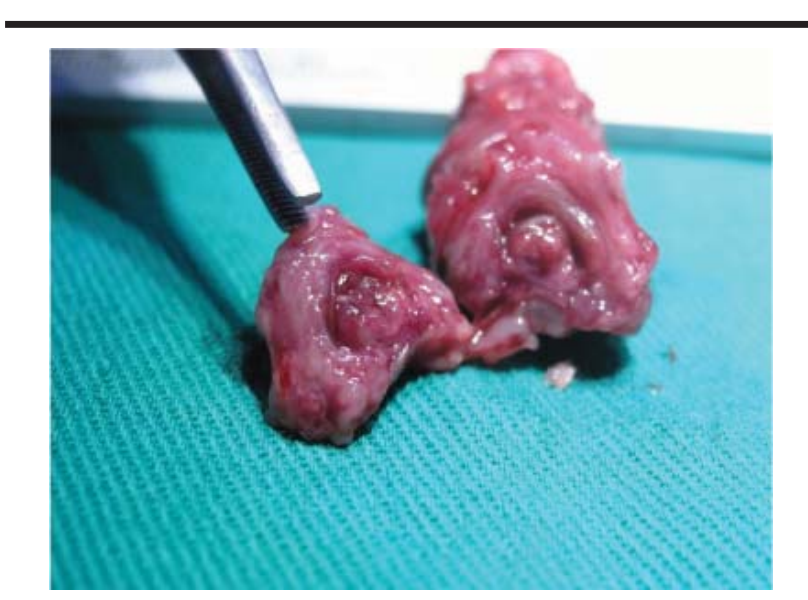

FIGURE 2 - Isolated vagina and cervix uteri

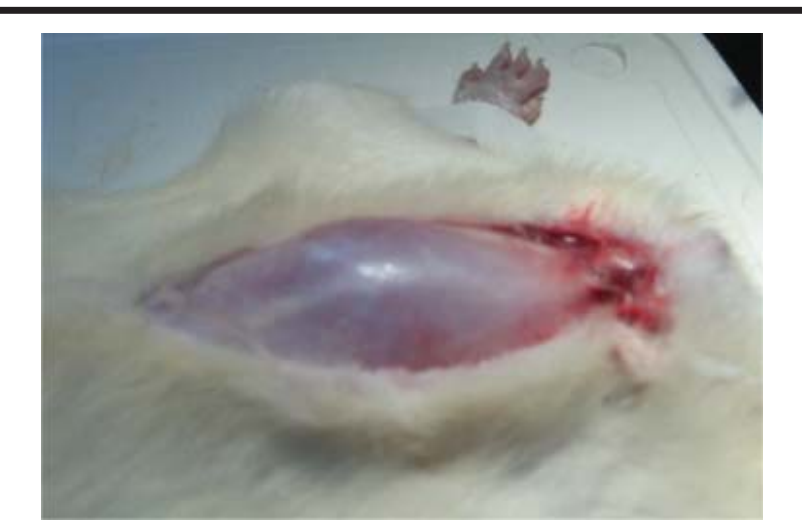

FIGURE 3 - Urine retention

TABLE 1 - Implantation and growth rate of Walker 256 carcinoma on vagina and cervix uteri

\begin{tabular}{cccc}
\hline Animals & Group A & Group B & Group C \\
\hline R1 & Y & Y & Y \\
R2 & N & Y & Y \\
R3 & N & Y & Y \\
R4 & N & Y & Y \\
R5 & N & Y & Y \\
\hline TOTAL & $20 \%$ & $100 \%$ & $100 \%$ \\
\hline Y
\end{tabular}

Y- macroscopic growth ; N - no macroscopic growth

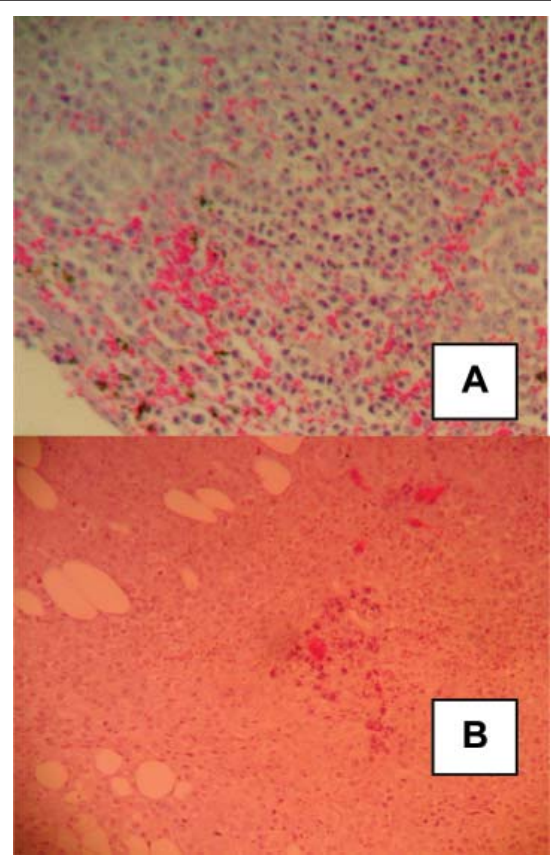

FIGURE 4 - Microscopic view of cervix uteri (A) and vagina (B). 40x view

TABLE 2 - Percentage of tumor weight equivalent to the body weight

\begin{tabular}{ccc}
\hline Animals & Group B & Group C \\
\hline R1 & 1.82 & 1.52 \\
R2 & 3.31 & 2.37 \\
R3 & 2.28 & 3.62 \\
R4 & 2.78 & 2.52 \\
R5 & 3.22 & 2.95 \\
\hline Average & 2.682 & 2.596 \\
\hline
\end{tabular}

\section{Discussion}

According to Brazil Cancer Incidence Estimative for 2006 cervical cancer was the third most common type of cancer in Brazilian women ${ }^{1}$. However, to the best of our knowledge, there are no reports of gynecological Walker carcinomas. On this model, inoculation of acetic acid before Walker 256 carcinoma inoculation was done in order to induce local inflammation which with vaginal wall scraping causes local lesion, therefore allowing Walker 256 carcinoma implantation and growth on vagina and cervix. Without previous acid acetic inoculation the lesion is inconsistent and uneven, with tumor growth on few rats. That agrees with Oliveira et $\mathrm{al}^{7}$ findings where the inoculation on gastric mucosa was only made possible with a previous lesion and Dornelas et $\mathrm{al}^{10}$ findings where tumor implantation happened only on the spot where the bladder was injured, demonstrating that unharmed mucosa does not allow tumor implantation. On both groups B and C the tumor implantation rate was 100\%, without difference between concentrations, similar to other inoculation Walker 256 carcinoma models, like kidney, ${ }^{9}$ bladder, 
10 stomach, ${ }^{7}$ mouth ${ }^{11}$ and others. In addition there was no difference between tumor behaviors on different concentrations, demonstrated with the absence of statistical relevance between tumor weight percentages. Despite the fact that on our work cells concentration does not influence on tumor behavior it is known that different concentrations influence on tumor bearing rats' longevity. ${ }^{5}$ However, on this study the survival rate was not evaluated. It is described that original Walker 256 carcinoma was an adenocarcinoma. However the organs on this work had an undifferentiated kind of tumor cells, without any possibility of distinguishing its type with hystological traditional techniques. That might have happened because of successive inoculations and difference between lineages of different laboratories. That undifferentiation would be also responsible for the tumor agressivity which invaded all vagina and cervix area, extending itself by contiguity to rectum.

\section{Conclusion}

According to the methods used, the Walker 256 carcinoma inoculation model into vagina and cervix have an implantation and growth rate of $100 \%$ when associated with previous acid acetic inoculation and there is no behavioral difference between using $2 \times 10^{6}$ or $4 \times 10^{6}$ cells on its inoculation.

\section{References}

1. Instituto Nacional de Câncer. Câncer do colo do útero [On Line]. Disponível em <http://www.inca.gov.br/ conteudo view.asp?id=326 $>$.Acessado em 13 de agosto de 2006.

2. Urrejola RS, Carrasco AMT, Heredia FM. Adenocarcinoma de células claras de la vagina. Rev Chil Obstet Ginecol. 2004;69(4):312-5.
3. Yagci G, Cetiner S, Dede M, Gunhan O. True vaginal metastasis of rectal cancer. Indian $\mathrm{J}$ Surg. 2005;67(5):270-2

4. Markman M. New, expanded, and modified use of approved antineoplastic agents in ovarian cancer. Oncologist. 2007;12(2):186-90

5. Moraes SP, Cunha A, Reis Neto JA, Barbosa H, Roncolatto CAP, Duarte RF. Modelo experimental de tumor de Walker. Acta Cir Bras. 2000;15(4):252-61.

6. Caldirola L, Dei Poli G, Dei Poli M, Bigliani S. Sullo sviluppo del tumore di Walker nella cute e nel tessuto sottocutaneo del ratto (Nota I). Min Chir. 1968;23:51-5.

7. Oliveira PFM, Henriques LA, Rodrigues-Filho F, Almeida PRC, Moraes MO. Estabelecimento de um modelo de tumor experimental pela inoculação do tumor de Walker em estômago de rato. Acta Cir Bras. 1998;13(4):243-8.

8. Gomes Neto A, Pessoa BBGP, Aguiar SA, Furtado BM, Moraes MO, Ribeiro RA. Modelo de tumor de pulmão em ratos com o carcinossarcoma de Walker. Acta Cir Bras. 2002;17(1):12-22.

9. Silva LFG, Soares FSD, Anselmo JNN, Fé DMM, Cavalcante JLBG, Moraes MO e col. Modelo de tumor experimental em rim de ratos. Acta Cir Bras. 2002;17(1):62-6.

10. Dornelas CA, Almeida PRC, Nascimento GL, Lima EB, Moraes MO. Modelo experimental do carcinossarcoma 256 de Walker em bexiga de ratos. Acta Cir Bras. 2006;21(1):38-42.

11. Alves APNN, Guedes RC, Costa-Lotufo LV, Moraes MEA, Pessoa CO, Ferreira FVA, Moraes MO. Modelo experimental de tumor na cavidade oral de ratos com carcinossarcoma de Walker 256. Acta Cir Bras. 2004;19(4):406-14.
Correspondence:

Nara Macedo Botelho Brito

Travessa Padre Eutíquio, 264/1101

66033-000 Belém - PA Brazil

narabrito@amazon.com.br
Conflict of interest: none

Financial source: none

Received: April 25, 2007

Review: June 21, 2007

Accepted: July 26, 2007

\section{How to cite this article}

Brito NMB, Brito MVH, Carvalho RKVC, Matos LTMB, Veloso TS, Vasconcelos DM, Brito RB. Experimental inoculation model of Walker 256 carcinoma into vagina and cervix uteri of female rats. Acta Cir Bras. [serial on the Internet] 2007 Nov-Dec;22(6). Available from URL: $\underline{\text { htp://www.scielo.br/acb }}$ 